\title{
Federal Energy Efficiency and Water Conservation Funding Study
}

Introduction 3

Findings 5

Energy Efficiency Investment Requirements 6

Water Conservation Investment Requirements ........................... 8

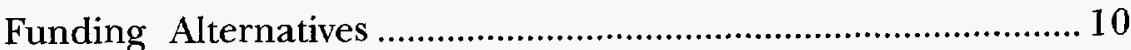

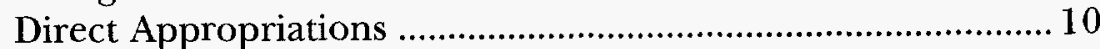

Energy Savings Performance Contracting............................... 11

Demand-Side Management ......................................................... 11

Federal Energy Efficiency Fund ........................................... 13

Establishing a Funding Mechanism ............................................ 14

Cost of Not Making Capital Available ........................................ 16

Capitalizing the Fund ............................................................. 17

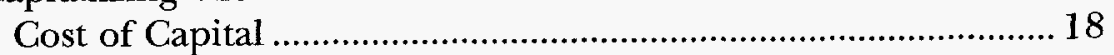

The Use of Non-Federal Funds .............................................. 18

Fund Replenishment ............................................................ 19

Minimizing Administrative Costs and

Maximizing Cost Savings ............................................... 21

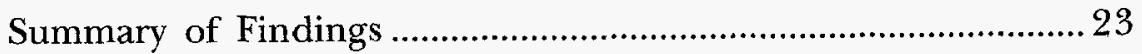

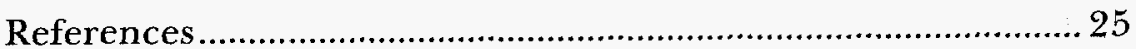

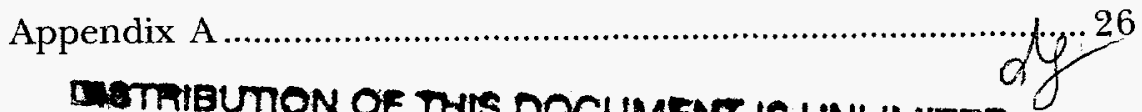
MASTER 


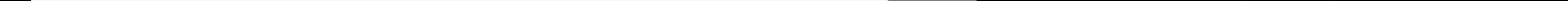




\section{DISCLAIMER}

Portions of this document may be illegible electronic image products. Images are produced from the best available original document. 


\section{ntroduction}

This report contains the results of a study required by section 162 of the Energy Policy Act of 1992 (EPAct). It outlines options for financing energy and water conservation measures at Federal facilities as required by Part 3 of Title $V$ of the National Energy Policy and Conservation Act (NECPA) (42 U.S.C. 8251 et seq.) as amended by EPAct. It addresses:

1) the estimated Federal financial investment necessary to install energy and water conservation measures to meet NECPA and Executive Order requirements;

2) the use of revolving funds and other funding mechanisms which offer stable, long-term financing of energy and water conservation measures; and,

3) the means for capitalizing such funds.

On March 8, 1994, President Clinton signed Executive Order 12902. This Executive Order is an aggressive mandate to improve energy efficiency and water conservation in Federal buildings nationwide. This Executive Order is designed to meet and exceed requirements for Federal energy and water efficiency that were contained in section 152 of EPAct. Section 152 mandated that Federal agencies use all cost effective measures with less than a ten year payback to reduce energy consumption in their facilities by 20 percent by the year 2000 compared to 1985 levels. In addition, Executive Order 12902 established a requirement to use cost effective measures to reduce energy use by fiscal year 2005 by 30 percent compared to 1985 energy use.

Both the EPAct and Executive Order reduction goals use 1985 as the baseline year. The baseline consumption in 1985 was 469.2 trillion Btus for Federal building energy use. By the year 2000 , the consumption should approach 356 trillion Btus and 311 trillion Btus in 2005. Consumption goals in Btus per gross square foot (Btu/GSF) for the year 2000 are 111,878 Btu/GSF and $97,893 \mathrm{Btu} / \mathrm{GSF}$ in 2005 . To achieve these goals, substantial investment in energy efficiency and water conservation will be required. The sources for this investment include: direct appropriations to agencies, private investment from energy savings performance contracts, utility investment from demandside management programs, and appropriations to the Federal Energy Efficiency Fund. 
Executive Order 12902 encourages and directs agencies to seek innovative non-Federal help in reducing their energy and water consumption. Section 401 of the Executive Order calls for the use of innovative financing and contractual mechanisms such as utility demand-side management programs and energy savings performance contracts. As noted in a March 1994 Office of Technology Assessment paper for the House Committee on the Budget, one of the major constraints to implementing more energy efficiency practices in the Federal government is the shortage of funds to invest in energy efficient equipment.

This report will provide estimates for the energy and water conservation investments needed to achieve the NECPA and Executive Order goals as well as estimates for the contribution from various funding sources and a review of the mechanisms for funding these investments. 


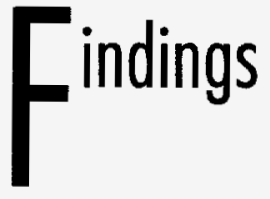

Estimating the investment necessary to achieve these goals and the likely source of funds for such investments requires evaluation of many dynamic variables. To estimate the amount of funds likely to be available, these variables include the amount of funding to be provided by direct appropriations to agencies as well as the level of non-Federal funds that will be available from utility programs and energy savings performance contracts. While historical information can provide indications of current funding, projections of future funding levels are much less certain. To estimate the total investment necessary to achieve the established goals, the variables would include the cost of energy and water, the energy and water conservation techniques, and the penetration of those techniques within the Federal sector. To reflect these many uncertainties, this report provides best estimates of investment requirements and funding sources, as well as an upper and lower level for each estimate. The range within these upper and lower bounds reflects the uncertainty of these estimates.

Based on an evaluation of the life-cycle cost effective energy and water conservation projects required to meet the NECPA and Executive Order goals, the best estimate of the total investment required between 1996 and 2005 is $\$ 5.7$ billion. This value could vary from a low of $\$ 4.4$ billion to a high of $\$ 7.1$ billion given the variability in both the energy and water investment requirements.

The best estimate of the total funding available from various sources to meet the energy and water investment needs between 1996 and 2005 is $\$ 3.7$ billion. This value could vary from a low of $\$ 1.8$ billion to a high of $\$ 4.5$ billion given the variability of the three primary sources of funding: direct appropriations, energy savings performance contracts, and utility demand-side management programs.

Using the "best estimate" values for both the required investment and funding availability, there would be a shortfall of $\$ 2.0$ billion in the funding necessary to achieve the NECPA and Executive Order goals. However, given the variability of the estimates, the shortfall could be as large as $\$ 5.3$ billion or, in the best case, there may be no shortfall. 
The table below summarizes the predicted values and the possible range of values for each investment account or funding source.

Investment and Funding Totals from 1996 to 2005 (in billions)

\begin{tabular}{|c|c|c|c|c|c|}
\hline \multicolumn{2}{|l|}{ Investment Needs } & \multicolumn{4}{|c|}{ Range } \\
\hline \multicolumn{2}{|c|}{ Best Estimate } & \multicolumn{2}{|c|}{ High-End Investment } & \multicolumn{2}{|c|}{ Low-End Investment } \\
\hline Energy Investment & $\$ 4.6$ & \multicolumn{2}{|c|}{$\$ 5.5$} & \multicolumn{2}{|c|}{$\$ 8.7$} \\
\hline Water Investment & $\$ 1.1$ & \multicolumn{2}{|c|}{$\$ 1.6$} & \multicolumn{2}{|c|}{$\$ .7$} \\
\hline Total & $\$ 5.7$ & \multicolumn{2}{|c|}{$\$ 7.1$} & \multicolumn{2}{|c|}{$\$ 4.4$} \\
\hline \multicolumn{6}{|c|}{ Expected Sources of Funding } \\
\hline \multicolumn{2}{|c|}{ Best Estimate } & $\begin{array}{l}\text { Low-End } \\
\text { Funding }\end{array}$ & $\begin{array}{l}\text { High-End } \\
\text { Funding }\end{array}$ & $\begin{array}{l}\text { Low-End } \\
\text { Funding }\end{array}$ & $\begin{array}{l}\text { High-End } \\
\text { Funding }\end{array}$ \\
\hline $\begin{array}{l}\text { Direct Agency } \\
\text { Appropriations }\end{array}$ & $\$ 2.4$ & $\$ 1.4$ & $\$ 2.8$ & $\$ 1.4$ & $\$ 2.8$ \\
\hline $\begin{array}{l}\text { Energy Performance } \\
\text { Contracts }\end{array}$ & $\$ .9$ & $\$ .3$ & $\$ 1.2$ & $\$ .3$ & $\$ 1.2$ \\
\hline $\begin{array}{l}\text { Utility Demand Side } \\
\text { Management }\end{array}$ & $\$ .4$ & $\$ .1$ & $\$ .5$ & $\$ .1$ & $\$ .5$ \\
\hline Total & $\$ 3.7$ & $\$ 1.8$ & $\$ 4.5$ & $\$ 1.8$ & $\$ 4.5$ \\
\hline Shortfall & $\$ 2.0$ & $\$ 5.3$ & $\$ 2.6$ & $\$ 2.7$ & $\$ 0.0$ \\
\hline
\end{tabular}




\section{Energy Efficiency Invesiment Requirements}

The techniques used to estimate energy savings potential and investment requirements are not based upon a comprehensive survey of Federal facilities. Instead, sampling and statistical techniques are used to derive the estimates that should accurately reflect the level of magnitude of funding required for future years.

The accuracy of these estimates is best captured by presenting the range of estimates for funding needs and expected sources of funding. As comprehensive facility surveys are conducted in accordance with the requirements of Executive Order 12902 these ranges and estimates can be further refined.

The estimates of energy efficiency investment are based upon two sources:

- 1993 US Army Corps of Engineers Renewables and Energy Efficiency Planning (REEP) Model;

- 1994 Pacific Northwest National Laboratory (PNNL) Estimates of Energy Efficiency in the Federal sector.

These two sources present a range of Btus saved annually per dollar invested from 18,071 to 19,441 . These values are probably slightly higher than the Federal sector as a whole due to the model's treatment of central heating plant and overseas energy pricing issues. Considering these issues, a more realistic value, and the value used in this study, is 15,000 BTU saved annually per dollar invested. This value of annual savings per dollar invested will be used in conjunction with the energy reduction requirements of 34 TBtus from an estimated 1996 consumption to that of the year 2000 and 69 TBtus by 2005 to determine the required investment. These energy reduction requirements translate into BTU/GSF goals of 111,878 by 2005 and 97,893 by 2005 .

Of these two sources, the REEP Model evaluated 72 energy conservation opportunities (ECOs) from 8 categories across 237 Department of Defense installations. This sample represents on 
the order of 60 percent of all Federal Government floor space. May 1994 computer modeling results reflect a potential savings, for this sample, of $\$ 554$ million per year with a total investment of $\$ 2.867$ billion. A non-discounted return on investment of approximately 2.7 was calculated for this study, indicating that the efficiency measures would pay back over two and one half times their original value. The discounted return on investment indicated that the savings would be approximately two times the original investment. (See Appendix A for an illustration of the effect of discount rates on savings projections.) Annual energy savings are predicted at 49.6 TBtus per year. The Department of Defense uses 71.6 percent of the total Federal government's building and facility energy. Assuming the efficiency measures projected to be implemented at the 237 installations analyzed represent the Department of Defense full 30 percent energy use reduction obligation at those facilities and that these measures represent all measures with less than 10 year payback periods, the total Federal government investment required between 1995 and 2005 to meet the savings requirements would be $\$ 4.8$ billion. Reducing this amount for investments made in 1995, the required investment for all energy efficiency measures from 1996 through 2005 is on the order of $\$ 4.6$ billion. This estimate may vary in either direction on the order of $\$ 900$ million due to uncertainty in energy prices for overseas installations, the treatment of central plants retrofit potential, and the estimates for dispersion of economic retrofit opportunities in specific facilities.

\section{Water Conservation Investment Requirements}

Estimating water conservation potential is much more difficult than estimating energy savings potential because similar data is not available for water projects. The gaps in available data include: 1) lack of usage and cost data collected by Federal agencies; 2 ) lack of readily available market cost data due to local availability of water; 3) lack of data on existing investment by agencies for capital or operational improvements in water conservation; 4) lack of data on the potential for third party financing from utilities, and state and local governments, and 5) lack of data on the potential for water conservation performance contracts. The one current principal source for information on water conservation in the 
Federal sector is the Environmental and Energy Study Institute's (EESI) June 1993 report, "Water Efficiency in Federal Facilities and Programs." Based upon a survey of some Federal agencies, the report estimates that the Federal water/ sewer bill approaches $\$ 1$ billion. The report further estimates that reducing water consumption by $10-15$ percent by implementing all retrofits with payback periods up to 20 years could save the government up to $\$ 150$ million annually. Since the NECPA requirement, as amended by EPAct, includes the installation of all water conservation projects with less than a ten year payback, and assuming that most (80 percent) water retrofits in the EESI study payback in less than ten years and the savings to investment ratio is similar to the energy conservation measures surveyed (close to 2.0), an investment level of $\$ 120$ million per year from 1996 to 2005 or $\$ 1.1$ billion would save the Federal Government $\$ 2.2$ billion in water costs, over the same period. This estimate may vary as much as $\$ 400$ million over the ten year period.

Two examples of the potential for water conservation in Federal facilities should be mentioned to demonstrate that substantial savings can be achieved with water conservation retrofits. In one involving a large Federal building in California, an audit has shown that water usage can be reduced by 50 percent and save $\$ 24,000$ per year. The payback period for the water retrofit is 4.7 years. The second example is a Federal Fisheries Science Center in Washington State. Here water recycling will reduce water use by 90 percent and save over $\$ 200,000$ per year, with a payback of less than four years.

Title V, Part 3, section 152 of EPAct, which amended NECPA, addresses water conservation by requiring a facility survey and the installation of water conservation measures with payback periods of less than ten years. Section 302 of Executive Order 12902 called for facility prioritization surveys by September 1995 followed by comprehensive facility audits during which 10 percent of an agency's facilities would be audited each year. As each agency conducts these audits over the next decade, water conservation measures will be identified.

Interest and activity have been increasing in water conservation within the utilities serving the Federal sector. A southern California electric utility has teamed up with a local water authority and others on a pilot, territory-wide DSM program directed at the Federal customer. GSA is one of the active participants. Although this pilot is designed to reduce 
energy consumption, water conservation opportunities will be addressed. In Boston, the Massachusetts Water Resources Authority provided a building water survey of the O'Neill Federal Building. Unlike the electric and gas utilities, which are regulated by state commissions which are the driving force behind the demand-side management programs, water providers are often simply unregulated resellers. As a result, water utilities are likely to need incentives, financial or otherwise, to become fully involved in demand-side management programs for water conservation in Federal facilities. Water shortages and pricing have been the motivators thus far. Extending the authority to enter into Energy Savings Performance Contracts from only energy to water conservation would also help stimulate the installation of water conservation measures.

\section{Funding Alternatives}

The four prime sources of funding currently sought for financing energy projects to meet the Federal consumption reduction requirements are:

- Direct appropriations to agencies;

- Demand-side management programs sponsored by utilities;

- Investments by Energy Saving Performance Contractors; and,

- The Federal Energy Efficiency Fund (FEEF).

Direct Appropriations: Given the many budget priorities that compete for energy and water conservation funding, direct appropriations have often not met energy efficiency funding needs. Although NEGPA requires each agency, in support of the President's annual budget request to Congress, to specifically identify funds requested for energy conservation measures, such amounts are not always specifically identified in appropriations bills. Most agencies group energy conservation dollars with capital equipment or operation and maintenance funds. In 1995, the Office of Management and Budget laid out a four-year funding plan to increase appropriations for energy efficiency projects within the four largest agencies (General Services Administration, Department of Defense, Department of Energy, and the Department of Veterans Affairs). Based on this funding plan, appropriations from 1995-1998 were projected to reach $\$ 1.5$ billion. However, the actual 1995 , 
1996, and 1997 DOE and DOD budgets were less than planned. Furthermore, the plan is approximately $\$ 160$ million/ year above the average actual expenditures experienced from 1985 to 1995 . Taking these factors into account, the conservative range of direct appropriations from 1996 to 2000 is estimated to be $\$ 700$ million to $\$ 1.4$ billion. If appropriations continue through 2005, this would result in a total from 1996 to 2005 of $\$ 1.4$ billion to $\$ 2.8$ billion.

Energy Savings Performance Contracting: Section 401 of Executive Order 12902 refers to the expected Federal agency use of innovative financing, such as energy savings performance contracting. Assigning a dollar value to available funds under this approach is extremely difficult due to the relatively small penetration of this contracting mechanism within the Federal sector. From FY 1987 through 1994, \$44 million has been invested in Federal energy conservation by means of energy savings performance contracts. However, contracting has increased substantially in the last two years, nearly doubling the previous total investment. Based upon what is known, planned projects, and the expected effort to seek and secure additional projects, it is estimated that over $\$ 180$ million will have been invested between 1996 and the year 2000 and $\$ 900$ million will have been invested between 1996 and 2005. The total invested by 2005 may be as little as $\$ 300$ million and as high as $\$ 1.2$ billion. This includes energy savings performance contracts and innovative utility financing mechanisms. Authority for performance contracts for other than building energy cost savings does not currently exist. However, the extension of such authority from energy to water and other areas could increase the non-Federal investment in water conservation.

Demand-Side Management (DSM): Utility sponsored incentive programs, also known as demand-side management programs, are valuable resources for the Federal sector. DSM activity in the form of customer rebates for energy efficiency investments is concentrated in a few regions, primarily the Northeast, California and the Pacific Northwest. States in other regions that have utilities which operate substantial DSM and incentive programs include: Wisconsin, Texas, Minnesota, Georgia, and Florida. A 1995 assessment showed that 13 utilities account for one-half of all utility DSM expenditures. Five utilities with the greatest expenditures accounted for 25 percent of the total expenditures on DSM. Utility DSM expenditures were expected to increase from 1.0 percent of 
utility revenue to almost 1.4 percent in 1995 , decreasing to 1.2 percent by the year 2001 .

With the onset of utility deregulation, many utilities have made aggressive moves to provide energy efficiency services to their customers as part of their utility services. Utilities are providing a variety of services from design to acquisition, installation, operation and maintenance of energy efficient equipment. The utilities are investing in equipment to be installed in Federal facilities and being repaid from the savings. The Energy Policy Act encouraged Federal facilities to take advantage of such incentives.

As demand side management rebates decline the utility incentive programs are likely to increase. Nationally, total expenditures for DSM rebate and other utility incentive programs are estimated to reach approximately $\$ 2.6$ billion in the year 2001. It is estimated that the utility commitment to DSM and incentive programs will remain constant at $\$ 2.5$ billion per year from 2001 through 2005. Total utility expenditures from 1991 through 2005 are expected to be near $\$ 36.5$ billion across all sectors of the economy.

Funding available through DSM and utility incentive programs is not static and varies over time. Annual changes in these programs are common. Some important factors affecting DSM funding levels include: the economy, interest rates, the Clean Air Act, surplus generating capacity, increasing competition among electricity suppliers, integrated resource planning, and the competition between gas and electric utilities. One of the major Northeast utilities which had been very active in DSM programs for the private and public sectors discontinued all such DSM programs in 1995 because it has determined that a surplus in generating capacity exists. Because the utility's end-use purchasing environment is changing, it wants to reposition itself as a full service provider to its customers, offering not only supply and demand side programs, but also a full range of services designed to maintain a solid customer base and maximize stockholders' return on investment. The uncertainty of utility deregulation is having a similar effect across the country.

Although electric utilities are required to report their DSM activities to the Department of Energy's Energy Information Administration (EIA), figures are not available for dollars spent on Federal government buildings specifically. It is estimated 
that the Federal share will be equal to the Federal building percentage of total domestic building energy consumption, which equals 1.3 percent. Given the expected level of DSM and utility incentive funding available nationwide and the Federal government share of total domestic energy consumption, it is estimated that the Federal building sector should take advantage of approximately $\$ 460$ million of the funds available from 1996 to 2005, assuming constant DSM and utility incentive funding levels. Given the increase in competition in the electricity supply sector and other pressures on utilities, the estimate for Federal DSM and utility incentive funding could range from a total of $\$ 90$ million to $\$ 450$ million over the period from 1995 to 2005.

Federal Energy Efficiency Fund (FEEF): EPAct established the Federal Energy Efficiency Fund as a dedicated centralized fund to provide grants to agencies to meet the NECPA energy and water conservation requirements. The fund provided grants to agencies based on competitively selected proposals. EPAct authorized $\$ 10$ million in fiscal year $1994, \$ 50$ million in fiscal year 1995 and such sums as may be necessary for fiscal years thereafter. Fiscal year 1994 appropriations for the fund were $\$ 6$ million, and $\$ 8$ million was appropriated in fiscal year 1995. There has been no funding appropriated for either fiscal year 1996 or 1997.

The fiscal year 1994 appropriations of $\$ 6$ million were fully subscribed within a six month period. This demand for funds did not include requests from the Departments of Defense, Veterans Affairs, Energy, and the General Services Administration. Proposals were not solicited from those agencies in fiscal year 1994 in keeping with the intent of appropriation committee language. The fund was oversubscribed in fiscal year 1995 and several high payback projects went unfunded.

While the FEEF represents one of the possible sources of funding for agencies to accomplish energy and water conservation projects, future year FEEF contributions to meet the investment needs are not specifically estimated in this study. Any future year appropriations to the FEEF would serve to minimize any shortfall which would result from insufficient funding from other sources to meet the investment needs. Therefore, appropriations for the FEEF will be considered as part of the funding that would reduce any shortfall. 


\section{Establishing a Funding Mechanism}

In addition to the importance of having funds available to implement energy and water conservation projects, the mechanism for providing those funds is also important. Different funding mechanisms provide different advantages and disadvantages depending on the capabilities, organization and staffing of the different agencies.

There are several mechanisms available to establish stable, long-term financing of energy and water conservation measures. These include:

1) continue project funding through a variety of formal and informal accounts within each agency;

2) establish a centralized grant making or revolving loan account for use by all agencies; and,

3) a combination of the two options.

Presently, a combination of formal and informal agency accounts, centralized grant making and revolving loan accounts exist within the Federal government to support energy and water conservation projects. An example of the formal account within an agency might be the Department of Defense Energy Conservation Investment Program. An example of the informal account might be any agency's operations and maintenance account which supports the installation of energy or water efficient equipment as part of the normal operations and maintenance activities by the agency. An example of a centralized grant making account is the Department of Energy Federal Energy Efficiency Fund. An example of a centralized, although limited, revolving account would be the General Services Administration Public Buildings Fund.

Each option offers advantages and disadvantages. The advantage of the formal agency account is that agencies can establish a structured approach for soliciting projects through well developed communications channels within the agency. Those agencies which have well structured energy conservation programs that could benefit from increased direct appropriations would not need to rely heavily on a centralized fund. Field staff at those agencies are continually made aware of the funding through internal agency announcements. The agencies can also identify their funding needs in the budget 
development process. One disadvantage is that the energy and water conservation needs of the agency are usually subordinated to other budget needs of the agency and generally do not receive adequate funding to support all cost effective project needs. Several agencies lack the well organized energy management programs needed to ensure adequate energy conservation funding from year to year. Such agencies can benefit from a centralized fund. A second disadvantage is that, in some cases, agency funds can be particularly narrow in focus, funding only project construction but not studies to identify worthy projects, or vice versa. This leads to inefficient allocation of some portion of the funding as projects with lower return on investment are funded because funding from another "pot of money" was not available to ensure the best projects were ready for funding. A third disadvantage is that many agencies do not need to establish a dedicated account or means of administering the funds or projects either due to the size of the agency or because the funds may be managed more cost effectively when spent through a broader capital equipment or operations and maintenance account.

One advantage of the centralized account is that it can cross agency lines to solicit and fund the best projects, ensuring that the limited resources provide the best return on investment. Another advantage is that the centralized account can have a broad focus in order to ensure that the variety of actions necessary to achieve the best projects can be funded. This broad focus can override many of the narrower rules and orders within the agencies which often hamper the efficient use of funds. When a centralized fund provides project funding using grants to agencies, as opposed to loans, the costs of administrative budgeting functions can be lowered. However, if the centralized fund were established as a revolving fund there would be a higher administrative cost to the government. A final advantage is that the centralized fund can be more flexible in allocation of funding to meet emerging needs. For example, an agency's budget request is started over one year before the funds will actually be received. This can result in a facility requesting and receiving funding for a project with the expectation of significant co-funding to be made by a utility demand side management program. With the rapid changes in the utility sector DSM programs, the utility contribution may not be available when the facility funding actually arrives. The facility or agency would then look for equal or better projects to 
fund. However, a centralized fund would have a wider array of options by looking at all the available projects within the Federal sector. The disadvantage is that the centralized fund will be less well known within the agencies without increased advertising expenses to reach the field staff.

The advantage of the combination of options, agency and centralized funds, is that the network for advertising the funding sources will be maintained within the agencies. The centralized fund also can act as a buffer or supplement to direct agency funding to stabilize the workload to match available agency resources and extend funding to an agency which has more conservation opportunities than it can complete with available funding. Since the centralized fund also can fund all necessary activities to ensure that the best projects are selected, it can ensure that those agency funds with a narrow focus can be directed toward the best projects. A centralized fund also can minimize funding shortfalls due to other competing and emergency agency budget priorities and can provide the flexibility and timely allocation of funds necessary to match emerging conservation opportunities. The disadvantage of a combination of agency and centralized funds is the slight increase in administrative overhead of managing a centralized account along with the costs of maintaining individual agency accounts.

\section{Cost of Not Making Capital Available}

The cost of having insufficient capital available to take advantage of all energy and water conservation opportunities far outweighs any other cost consideration. For example, ignoring the effect of discount rates, for each year that adequate capital is not available to accomplish a project with a three year payback, one year of savings from the project is lost. Those savings are roughly equal to 30 percent of the capital required to accomplish the project. In essence, the cost of not having capital available to accomplish such a project is 30 percent of the investment required. In simplistic terms, the cost of not having capital available for projects with a ten year payback is 10 percent for every year that the project is delayed. 
These costs due to lost savings are a real expense as surely as interest charges are a necessary expense of making the capital available. Since the Army REEP study found that the average discounted payback period for most projects was approximately 4.5 years, it can be simply estimated that the cost of a one year delay for projects would be on average about 22 percent of the total investment cost. Since this value far exceeds the highest cost of capital that would be seen even in the private sector, it is obvious that the cost of delaying projects due to insufficient capital creates far more expense than would the cost of funding projects with more expensive capital.

On a Federal wide basis, the cost of delays in funding projects is equal to the annual savings that are not achieved due to a lack of funding. Again, extrapolating the Army REEP analysis to the remainder of the Federal sector indicates annual energy cost reductions of approximately $\$ 1.0$ billion per year are yet to be achieved. This would indicate that the cost of insufficient capital is approaching $\$ 1.0$ billion a year in lost savings. While it is not practical to immediately increase Federal funding to the estimated $\$ 5.7$ billion level necessary to accomplish all projects and achieve these cost reductions, a significant increase appears to be warranted, even at the higher costs of capital available from non-federal funding sources.

Having insufficient capital available has the greatest impact on achieving energy, water and cost savings.

\section{Capitalizing the Fund}

The greatest challenge to establishing any funding mechanism is finding a way to build up the initial capital in the fund. This capital can then be used to fund individual energy efficiency and water conservation projects.

There are many options for capitalizing such government funds. The principal considerations in choosing these options are:

- the cost of capital;

- the use of non-Federal funds;

- fund replenishment; and,

- minimizing administrative costs and maximizing cost savings. 
Contributing to the complexity of these issues are the various alternatives of using revolving funds, direct appropriations or a combination of the two. Each has a bearing on the fund's ability to act as a vehicle to achieve the energy performance requirement of NECPA and Executive Order 12902.

Cost of Capital: The cost of capital has a direct effect on the cost effectiveness of energy and water conservation projects. The more expensive the capital, the more expensive the project and the more likely it is that some number of projects will be eliminated from consideration because they do not meet the payback criteria established in NECPA. Conversely, low cost capital means more projects will be cost effective and will be accomplished, thereby generating more energy, water and cost savings.

The lowest cost of capital for any fund would be achieved by use of Government appropriations. Appropriations provide financing at the Government borrowing rate. Current borrowing costs are in the four to seven percent range.

If non-Federal sources of funding were used to finance projects through energy savings performance contracts, the cost of capital would likely be closer to the commercial market rates for funds, which is generally a few percentage points above the Government rate. There may be opportunities to lower the cost of capital due to improved investor confidence, by establishing a secondary market for energy efficiency financing. However, even with such a market in place, privately financed projects are likely to experience a cost of capital above the Government rate.

The Use of Non-Federal Funds: As stated above, the interest costs of using non-Federal funds are greater than the interest costs associated with using Federal funds. However, in the absence of full Federal funding to take advantage of all energy and water conservation opportunities, the use of non-Federal funds to finance conservation measures can be much less expensive than delaying projects until the Federal funds become available. This fact supports the use of non-Federal funding in Energy Savings Performance Contracting where a contractor finances, acquires, installs, and maintains the energy saving equipment.

Another possible means of using non-Federal funding could include the use of private funding strictly to finance Federal 
projects. This approach, which would require new legislation, would differ from energy savings performance contracting in that this alternative approach might allow agencies to borrow funds from non-Federal sources for the very limited purpose of financing cost effective energy and water conservation projects. The agency would be responsible for the procurement, installation, operation, and maintenance of the equipment. The agency would also be responsible for repayment of the loan. This repayment would come from appropriations to the agency but the loan repayment amounts would be offset by lower utility costs.

In formulating such an approach, a variety of issues would need to be considered. These would include: the conditions under which an agency would be allowed to borrow funds; the centralization of borrowing on behalf of the Government; limitations on the amounts and rates at which funds would be borrowed; and the mechanism for administering such an approach. The Department of Energy is currently reviewing the successful use of this model by several state and local governments. Any such alternative would clearly represent a substantial change in the Federal budgeting process and would require careful consideration of the complexities discussed below.

Fund Replenishment: A conventional appropriations or grant approach does not contribute to the replenishment of fund capital resources because it does not have to be paid back. In this case, the fund would need to be replenished each fiscal year by additional appropriations.

While a revolving fund may appear to solve the need for annual appropriations, in fact, it will simply be replenished by appropriated funds from the agencies appropriations for operations or utility accounts. Therefore, there is minimal impact on the level of Federal appropriations required. For example, with conventional appropriations, an agency may seek $\$ 50$ million to accomplish proposed energy conservation projects. Once appropriated, the agency would accomplish the projects and no further budget action would be required. With a revolving fund, the fund would seek appropriations for a particular year. An agency could then use $\$ 50$ million from the fund, accomplish the projects, and over the next several fiscal years would seek appropriations to repay the fund. The agency's appropriation requests would be more than offset by lower requests for utility accounts but appropriations would still 
be necessary to repay the loan. To ensure that the loans in any particular year did not become excessive when taken in the context of all other budget pressures, Congress would likely set a yearly limit on the amount of money that could be borrowed. In essence this yearly limit on loan amounts is comparable to the annual limits on appropriations to all agencies for energy and water conservation projects. In addition, the annual appropriations to agencies to repay the loans is similar to the yearly appropriations of amounts to individual agencies to complete projects.

Revolving funds which are offset by revenues derived from other federal funding sources provide the flexibility to fund unstable expenditures associated with providing a product or service such as the manufacture of defense consumables. A revolving fund for energy and water conservation could stabilize the variable appropriations stream for funding energy and water conservation measures. However, unlike other revolving funds, it could also reduce the expenses associated with providing the government products and services. The stabilization of the variable appropriations stream would allow agencies to plan with greater certainty the execution of their work on a more timely basis by being able to request funds when resources were available to complete the projects. However the stability of the revolving fund would only occur if the authorized limits to the amount of borrowing from the fund were stable from year to year. The current annual appropriations approach tends to cause uneven workloads throughout the year and from year to year. Authorization limits on the amount of borrowing from a revolving fund that varied from year to year would also cause uneven workloads throughout the year and from year to year.

Another advantage of the revolving fund approach is that the fund could make loans to those agencies which have the greatest opportunity for savings and rapid repayment. This would cycle the funds through the revolving fund more quickly than if each agency attempted to expend appropriated funds on only the best projects within the agency. More rapid cycling of the funds would lower the overall cost to the Federal government of not having adequate funds available within any agency.

In summary, the use of a centralized revolving fund can replenish the capital in the fund and thereby ensure funding for additional energy, water, and cost savings projects. 
However, constraints placed on the operation of Federal revolving funds, such as caps on the amount to be loaned, could leave the fund under-capitalized and generate a significant expense in lost energy, water, and cost savings.

Minimizing Administrative Costs and Maximizing Cost Savings: The greater administrative/overhead cost of a revolving loan program is one of the disadvantages of such an approach. For example, the Federal Energy Efficiency Fund, which operated as a grant program, was run by one Federal employee with some contract assistance. With a revolving loan fund, each agency that received a loan would be required to track the loan repayment in a budget office through several years until fully repaid. This would increase the burden and costs on the agencies beyond that found in a grant program like the Federal Energy Efficiency Fund. For that reason, the direct appropriations approach minimizes the cost of administering the budgeting of energy and water conservation projects.

The best way to maximize cost savings is to ensure that funding is available to accomplish all energy and water conservation projects as soon as resources are available to support the workload. This requires that funding be applied to the correct budget accounts to support the study, design, procurement, construction or retrofit of any project which is cost effective. Adequate direct appropriations to agencies and a centralized account which can supplement direct appropriations as the needs for funds become available can solve the problem of providing funding when the resources are available. In addition, if the restrictions on the use of the funds are kept to a minimum, and performance of the funded portfolio of projects is used as a measure of success, then a central fund can meet the needs of supporting the different budget accounts such as studies, design, projects, etc.

Therefore, a combination of direct appropriations and a centralized account which can fund the best energy and water conservation projects, or activities which lead to successful projects, can maximize the energy, water and cost savings when compared to a variety of separately funded agency accounts which are saddled with spending limitations and compete for funds against other budget priorities.

In addition to projects which result in energy efficiency or water conservation improvements, there are related energy and water projects which, while not improving the efficiency of the resource use, can reduce costs. An example is the use of 
thermal energy storage which shifts the energy use for air conditioning from times of peak demand and expensive rates to times of lower rates. Although no energy is saved, and in some cases, more energy is used, the cost savings far outweigh the increased energy use. While not satisfying the requirements of NECPA or the Executive Order, it is recommended that these projects be funded under any approved funding mechanism for their value in reducing the cost of government operations. 
Based upon the discussion above, the Department of Energy finds that:

The funding requirements and likely sources of funds available to achieve the NECPA and Executive Order energy and water savings from 1996 through 2005 are shown in the following table:

Investment and Funding Totals from 1996 to 2005 (in billions)

\begin{tabular}{|c|c|c|c|c|c|}
\hline \multicolumn{2}{|l|}{ Investment Needs } & \multicolumn{4}{|c|}{ Range } \\
\hline & st Estimate & \multicolumn{2}{|c|}{ High-End Investment } & \multicolumn{2}{|c|}{ Low-End Investment } \\
\hline Energy Investment & $\$ 4.6$ & \multicolumn{2}{|c|}{$\$ 5.5$} & \multicolumn{2}{|c|}{$\$ 3.7$} \\
\hline Water Investment & $\$ 1.1$ & \multicolumn{2}{|c|}{$\$ 1.6$} & \multicolumn{2}{|c|}{$\$ .7$} \\
\hline Total & $\$ 5.7$ & \multicolumn{2}{|c|}{$\$ 7.1$} & \multicolumn{2}{|c|}{$\$ 4.4$} \\
\hline \multicolumn{6}{|c|}{ Expected Sources of Funding } \\
\hline & st Estimate & $\begin{array}{l}\text { Low-End } \\
\text { Funding }\end{array}$ & $\begin{array}{l}\text { High-End } \\
\text { Funding }\end{array}$ & $\begin{array}{l}\text { Low-End } \\
\text { Funding }\end{array}$ & $\begin{array}{l}\text { High-End } \\
\text { Funding }\end{array}$ \\
\hline $\begin{array}{l}\text { Direct Agency } \\
\text { Appropriations }\end{array}$ & $\$ 2.4$ & $\$ 1.4$ & $\$ 2.8$ & $\$ 1.4$ & $\$ 2.8$ \\
\hline $\begin{array}{l}\text { Energy Performance } \\
\text { Contracts }\end{array}$ & $\$ .9$ & $\$ .3$ & $\$ 1.2$ & $\$ .3$ & $\$ 1.2$ \\
\hline $\begin{array}{l}\text { Udility Demand Side } \\
\text { Management }\end{array}$ & $\$ .4$ & $\$ .1$ & $\$ .5$ & $\$ .1$ & $\$ .5$ \\
\hline Total & $\$ 3.7$ & $\$ 1.8$ & $\$ 4.5$ & $\$ 1.8$ & $\$ 4.5$ \\
\hline Shortfall & $\$ 2.0$ & $\$ 5.3$ & $\$ 2.6$ & $\$ 2.7$ & $\$ 0.0$ \\
\hline
\end{tabular}

The Department of Energy also finds that:

The cost of not having sufficient funds available to achieve all cost effective energy and water conservation opportunities in the Federal building sector is on the order of $\$ 1.0$ billion per year in excessive energy costs;

Agencies which have well-established energy and water conservation programs will benefit most from receiving a majority of funding by direct appropriations to the agency;

A centralized fund can be most effective by providing supplementary funds, as needed, to agencies that have well established and substantially funded energy and water conservation programs, as well as providing a dedicated source 
of funds for use by agencies which do not have well established energy and water conservation programs;

The use of a combination of direct appropriations to agencies and to a centralized fund can increase the energy and water cost savings compared to the use of only direct appropriations to agency accounts;

The use of a revolving fund will increase the administrative costs of providing funds for energy and water conservation projects compared to direct appropriations;

The use of a revolving fund may not ensure a stable funding source for energy and water conservation since revolving funds will likely be subject to the potential destabilizing effects of limits on annual authorizations as a means of controlling spending authority, in a manner similar to current limits on direct appropriations for energy or water conservation projects;

The use of higher cost, non-Federal funds for energy savings performance contracts is generally less expensive than delaying energy conservation projects until lower cost Federal funds become available;

The authority to enter into performance contracts to achieve water or water cost savings, without saving energy, does not currently exist and, if authorized could increase the potential investment of non-Federal funds; and

The use of non-Federal funds to finance energy and water cost saving projects which could be accomplished by methods other than energy savings performance contracts is being studied as a means of supplementing any shortfalls in Federal funding and providing a stable long term source of funding. 


\section{References}

1. Federal Energy Efficiency Fund: Needs Assessment and Benefits Analysis, Examination of State Experience, and Administrative Issues, Advanced Sciences, Inc. March 31, 1993, Prepared for the Office of Federal Energy Management Programs, U.S. Department of Energy, Washington, D.C.

2. Federal Energy Efficiency Fund for Reducing Energy Consumption in Existing Federal Buildings. Princeton Synergetics, Inc. May 1992, Prepared for the Office of Federal Energy Management Programs, U.S. Department of Energy, Washington, D.C.

3. Financing the Future, Report of the Commission to Promote Investment in America's Infrastructure, February 1993, available from the Office of Economics, U.S. Department of Transportation, Washington, D.C.

4. Water Efficiency in Federal Facilities and Programs, June 1993, Marilyn L. Arnold and Don Gray, Environmental and Energy Study Institute, Washington, D.C.

5. Draft Report Water Management Study, Chet Holifield Federal Building, Laguna Niguel, California, February 1994, Pequod Associates Inc., Prepared for the Metropolitan Water District of Southern California.

6. Water Circulation Potential in Fish Culture at the Northwest Fisheries Science Center, September 24, 1993, Northwest Fisheries Science Center, National Marine Fisheries Service, Seattle, Washington.

7. Executive Order 12902, Energy Efficiency and Water Conservation at Federal Facilities, March 8, 1994. The White House, Washington D.C.

8. Electric-Utility DSM Program Costs and Effects: 1991 to 2001, Eric Hirst, May 1993, Oak Ridge National Lab (ORNL) Energy Division.

9. Annual DSM Industry Report 1993. Prepared by Energetics, Inc. for the Assoc. of DSM Professional Managers, 1994.

10. Electric Power Annual - 1992, Energy Information Administration, 1993.

11. Annual Report to Congress on Federal Govermment Energy Management and Conservation Programs FY 92, U.S.DOE, 1994.

12. Utility Demand-Side Management Programs: A Framework for Strategic Planning, prepared for U.S. DOE FEMP, 1994.

13. Renewables and Energy Efficiency Planning (REEP) Study, U.S. Army Concepts Analysis Agency Progress Report, July 1994.

14. Energy Policy Act, P.L 102-486-October 24,1992, 102d Congress. 


\section{The Economics of Energy Efficiency and Water Conservation Investments}

\section{Appendix A}

The discussion of the results of the Army REEP analysis and water conservation investments includes many of the important elements of the economics of efficiency investments. Key factors discussed include:

- the energy savings goals;

- the investment cost to achieve the goals;

- the rate at which the project delivers the cost savings;

- the number of years a project will continue to return savings; and,

- the total cost savings in future energy bills.

In addition to these factors are the underlying economic factors of the economy including:

- the interest rate at which funds are borrowed to make the investments; and,

- the future escalation of the prices of energy and construction costs.

Use of these factors can form the fundamental relationships of any energy project. These relationships are defined by such terms as simple payback period, discounted payback period, savings to investment ratio and return on investment. 
Using a simple example, of an inefficient electric motor being replaced by an efficient motor, the following conditions will illustrate the relationships.

-- The original motor used 20,000 kilowatt hours per year of electricity.

-- The new motor is 10 percent more efficient and will consume only 18,000 kilowatt hours per year of electricity.

-- The savings will be 2,000 kilowatt hours per year of electricity.

-- The new motor will deliver savings for 15 years before an investment in another new motor will be required.

-- The investment cost for the new motor is $\$ 450$ more than the old motor.

-- The current cost of electricity is $\mathbf{5}$ cents per kilowatt hour.

-- Electricity costs are expected to stay stable at 5 cents per kilowatt hour into the future.

-- Borrowing rates to make the investment are 8 percent per year.

The calculation of the economics would yield the following:

-- The total investment increase for the motor is $\$ 450$.

-- The energy cost savings per year is: 2000 kilowatt hours X 5 cents per kilowatt hour, for a total of $\$ 100$ per year.

-- The simple payback for this investment is: $\$ 450$ invested / $\$ 100$ saved per year, for a simple payback of 4.5 years for the original investment.

-- Over the 15 year life of the motor investment, a total cost savings of 15 years X $\$ 100$ per year, or $\$ 1500$ would result.

-- The savings to investment ratio would be: $\$ 1500 / \$ 450$, for a total of 3.33 This is also called the non-discounted return on investment. The net savings would be $\$ 1050$ for this project.

- When the borrowing rate is factored in to reduce, or discount, the value of dollar savings in later years, the total value of savings over the life of the motor investment approaches $\$ 900$ instead of $\$ 1500$. (In essence, the 8 percent borrowing rate means that the savings delivered in each future year are worth 8 percent less that the preceding year.)

-- With a total discounted savings of nearly $\$ 900$, the discounted savings to investment ratio is $\$ 900 / \$ 450$ or 2.0 . This is also called the discounted return on investment of the project. The net discounted savings would be $\$ 450$ for this project.

-- When the borrowing rate is factored into the payback calculation, the pay back period becomes slightly longer. In this case it takes 5.3 years to pay back the investment so the discounted payback period is 5.3 years. 